\title{
Study on Existing Problems and Reform Paths of VAT System in China's Financial Industry
}

\author{
Chunyan Zhang \\ International Law Department \\ Foreign Affairs University \\ Beijing, China
}

\begin{abstract}
Since the Chinese government has started the tax reform of "the Change from Business Tax to Value-Added Tax" in 2012, how to levy the value-added tax in finance industry has become the focus of the industry. In order to protect the stability of tax base in financial industry after the implementation of "the Change from Business Tax to ValueAdded Tax" and the smooth transition of reform, the policymaking department has maximally extend the tax policy and means of tax collection in the original business tax. However, China is one of the first countries in the world to impose VAT on the financial industry. With the complexity and innovation of financial industry itself, therefore, it is difficult to step in place to "the Change from Business Tax to Value-Added Tax". In order to maximize the neutral advantage of value-added tax, it is suggested that in the next reform, the scope of tax payment for value-added tax in financial industry be further adjusted, and the deduction chain of value-added tax be improved.
\end{abstract}

Keywords-value-added tax in financial industry; "the change from business tax to value-added tax"; tax reform

\section{INTRODUCTION}

The value-added tax system levies the tax from the final consumption and can maintain the tax neutrality in the process of production and international trade. Therefore, it is widely regarded as a relatively friendly and growing tax. ${ }^{1}$ In order to adapt to the current economic system and management capacity of tax collection, the Chinese government has started the tax reform of "the Change from Business Tax to Value-Added Tax" since 2012, and decided since May 1, 2016, to implement the pilot of "the Change from Business Tax to Value-Added Tax"" throughout the country. Then all industries that previously belonged to the scope of sales tax are converted to VAT. This is another profound change in China's fiscal and taxation system since the reform of tax system in 1994.

In the process of promoting the reform of "the Change from Business Tax to Value-Added Tax", the financial industry has been considered as the industry's key and difficult area. On the one hand, from a global perspective, how to impose VAT in the financial industry is a worldwide problem. So far, the specific measures are different that have

OECD: Consumption Tax Trends 2014: VAT/GST and Excise Rates, Trends and Policy Issues. OECD Publishing. 19 Dec 2014. been taken by countries that impose VAT in the financial industry, and no country has yet established a widely recognized, scientifically sound system of value-added tax in financial industry. The methods of VAT have advantages and disadvantages, and there is very few direct reference of international experience for China. On the other hand, the characteristics of financial industry and the complexity of its business have also led to a more complex situation than other industries in the process of "the Change from Business Tax to Value-Added Tax": With the advent of information age and Internet economy, finance is an important part of modern service industry, which presents the transaction complexity, diversification of framework of financial commodity, the emptiness of subject caused by financial disintermediation trend, etc. Inevitably, there will be some conflicts and problems at the macro and micro levels. ${ }^{2}$ At the same time, the financial services terminal almost includes all enterprises and individual consumers. The particularity and universality of customers not only make it impossible to offset the ticket, and it also increases tax staff's tax calculation and collection difficulty. Therefore, since the implementation of China's" the Change from Business Tax to Value-Added Tax", how to levy VAT in financial industry has been a hot issue in the academic and practical circles.

In this background, China's reform of "the Change from Business Tax to Value-Added Tax" in financial industry is an innovation and basically a feeling of "Crossing the river by feeling the stones". In March 23, 2016, the Ministry of Finance and the State Administration of Taxation jointly promulgated Circular on Comprehensively Pushing the Pilot of VAT of Business Tax Reform, which declares that since May 1, 2016, consumer value-added tax has been introduced nationwide, including the financial industry. Subsequently, in April 29th and June 30th, two ministries and commissions issued Circular on Further Clarifying and Comprehensively Pushing the Relevant Policies to Increase the Pilot of "the Change from Business Tax to Value-Added Tax" in finance industry and Supplementary Notice on Value-Added Tax Policies from Inter-Bank Transactions of Financial Institutions. The transition policies in finance industry during the period of "the Change from Business Tax to Value-

Fan Yong: Steady Promotion of Reform of Financial Industry's "the Change from Business Tax to Value-Added Tax", published in Financial Times, version 004, April 16, 2016. 
Added Tax" have been described in more detail. Since then, China's financial industry has entered a comprehensive era of value-added tax.

Generally China's current value-added tax system in the financial industry is in line with China's national conditions, which has made remarkable achievements in reducing the overall tax burden of financial industry, avoiding repeated taxation and promoting the development of financial industry. However, China is one of the first countries in the world to impose VAT on the financial industry. With the complexity and innovation of financial industry itself, therefore, it is difficult to step in place to "the Change from Business Tax to Value-Added Tax". And the existing value-added tax system in financial industry still has some problems that are inevitable.

\section{ANALYSIS OF CHINA'S CURRENT VALUE-ADDED TAX SYSTEM IN THE FINANCIAL INDUSTRY}

In order to ensure the stability of tax base after the implementation of "the Change from Business Tax to ValueAdded Tax" in the financial industry and the smooth transition of reform, the policymaking department has maximally extend the tax policy and means of tax collection in the original business tax. Specifically, China's current value-added tax system of financial industry shows the following characteristics:

\section{A. The Value-Added Tax Shall Be Generally Levied on Taxpayers Who Have Paid Sales Tax.}

After the implementation of "the Change from Business Tax to Value-Added Tax" the financial taxpayers still are the units and individuals that sell financial services within the territory of China, which can be divided into the general taxpayer and small-scale taxpayers specifically. The taxpayers whose annual value-added tax sales of taxable behavior are more than 5 million yuan are the general taxpayer, and the others whose annual value-added tax sales do not exceed the prescribed standards are small-scale taxpayers. Taxpayers who have the duty to pay tax shall not pay business tax but should pay VAT from May $1,2016^{3}$.

In the scope of tax payment, the existing value-added tax system of financial industry adjust the previous tax items of financial business, of which the six categories of business include loans financial leasing, transfer of financial products, financial brokerage business, other financial services, insurance services and so on, to the four major that include categories current loan services, direct fees, financial services, insurance services and transfers of financial products. In other words, the financing lease of original business tax and financial brokerage business are classified as the direct charge of financial services.

According to the definition of taxable behavior of financial industry in current legal system, China's value-

${ }^{3}$ See Annex 3 of Circular on Comprehensively Pushing out Pilot Projects on "the Change from Business Tax to Value-Added Tax" of Ministry of Finance and State Administration of Taxation: the regulations of relevant matters: the provisions of transitional policy. added tax on the financial industry shall be not judged by the nature of industry which the taxpayer is engaged in but by the specific taxable behavior of taxpayers. In other words, for financial services, if any taxable behavior within the scope of financial services that have been defined even not from financial institutions, the value-added tax should be calculated on the basis of financial services, so as to ensure the stability of tax base after the implementation of "the Change from Business Tax to Value-Added Tax" effectively.

\section{B. The Original Preferential Tax Policy in Business Tax Is Continued.}

The current value-added tax system in the financial industry has stipulated the tax-free items of taxpayers in detail, which maximally continue the original preferential tax policy in business tax. After the implementation of "the Change from Business Tax to Value-Added Tax", the items originally exempted or exempted under the sales tax continue to be exempt from VAT such as the specified treasury bonds and interest income of local government bonds, interest income from transactions with financial interbank, lending services to key industries, life-insurance return business for more than one year and premium income of health insurance for more than one year. At the same time, the scope of exemption of "financial interbank transactions" has been further expanded, of which the applicable scope of "financial interbank transactions" absorbs the interbank deposits, interbank loans, interbank deposits, interbank payment, outright buyout of resale financial products and financial holding bonds.

Beyond that, after the "the Change from Business Tax to Value-Added Tax" in the financial industry, in order to enhance the international competitiveness of cross-border financial services, some cross-border financial services, as well as qualified foreign investors (QFII)entrust domestic companies to engage in securities trading business in China. And Hongkong investors buy A share listed in Shanghai Stock Exchange through Shanghai-Hong Kong Stock Connect; Hongkong investors mutually recognize and buy mainland fund shares through funds; Securities fund managers use funds to buy and sell shares; The transfer income and so on has also been included in the tax-free range in the transition policy; these are carried out in order to achieve the goal "Ensure that the tax burden of financial industry is decreasing but not increasing, so as to stabilize the market expectation. 4

\section{There Is No Substantial Change in the Main Tax Basis.}

Before "the Change from Business Tax to Value-Added Tax", the main basis of the business tax levied in China's financial industry is the "Turnover", and there are two paths to confirm the turnover: One is the intermediary services such as loan, pawn, financial brokerage, etc, of which the total amount of earned interest or commission income is

\footnotetext{
${ }^{4}$ China Securities Network: Li Keqiang: Ensure that the tax bearing of "the Change from Business Tax to Value-Added Tax" in financial industry is only reduced but not increased. http://finance.sina.com.cn/roll/2016-0621/doc-ifxtfsae5978072.shtml, visited in August 24, 2016.
} 
defined as turnover; The other one is the transfer of financial products such as foreign exchange, securities, futures, of which the difference between the selling price and buying price is the turnover of taxpayer.

After "the Change from Business Tax to Value-Added Tax", China's value-added tax has two major types of taxation, which are a simple method of tax assessment for small-scale taxpayers and a general method of tax assessment for general taxpayers. The taxable amount of simple tax method is calculated on the basis of the rate of sales and VAT; the general calculation method is calculated on the basis of the current balance deducted by the input tax of the VAT taxpayer. Whatever any method is taken, the most important tax basis is the taxpayer's "Amount of sales", which is all prices and the cost the taxpayers obtained from taxable behavior. It can be seen that, compared with the previous tax basis of "Amount of sales" of business tax, the tax basis of "Amount of sales" of value-added tax in finance industry did not change substantially after the implementation of "the Change from Business Tax to ValueAdded Tax". That is not only good for taxpayers and tax authorities to pay taxes and levy, but also to protect the smooth transition of "the Change from Business Tax to Value-Added Tax".

\section{THE Challenge OF "THE CHANGE FROM BUSINESS} TAX TO VALUE-ADDED TAX" IN THE FINANCIAL INDUSTRY TO THE CURRENT TAX SYSTEM

"The Change from Business Tax to Value-Added Tax" in financial industry is an important part of China's structural tax-reduction policy, also an important means to optimize the economic structure and change the mode of economic development. ${ }^{5}$ Due to the complexity and innovation development of financial industry, it is difficult to step in place to "the Change from Business Tax to Value-Added Tax". Therefore, the existing value-added tax system in financial industry still has some problems that bring some challenges to China's ongoing tax reform as follows:

\section{A. A Unified Tax Rate Is Not Conducive to Take the Advantage of Tax Neutrality of Value-Added Tax.}

The tax rate is the main index to measure the tax burden, and the tax rate determined is crucial to "the Change from Business Tax to Value-Added Tax". Before the comprehensive implementation of "the Change from Business Tax to Value-Added Tax" in the financial industry, how to determine the tax rate has become the focus of hot debate in the academic circles. At present, China's valueadded tax has two major types of taxation, which are a general method of tax assessment for general taxpayers and a simple method of tax assessment for small-scale taxpayers. Normally, in general taxation method, the output is subtracted by balance of input is the taxable amount; In the simple tax method, the tax payable is calculated on the basis of the collection rate of sales and VAT, and the input tax

${ }^{5}$ He Jian: Discussion on practice path of "the Change from Business Tax to Value-Added Tax" in China's Financial Industry, published in Gansu Finance, 2015, $3^{\text {rd }}$ issue, Page 60. shall be not deducted. In accordance with the two types of taxation, the VAT rate of $6 \%$ is applicable to the general taxpayer of value-added tax in the financial industry applies. And the VAT rate of $3 \%$ is applicable to the business service provided by small-scale taxpayers and financial service with simple tax options provided by the general taxpayer in particular financial institutions.

In other words, whatever service the general financial taxpayers provide, it is available for the unified VAT of $6 \%$. However, such a unified tax rate does not well reflect the tax neutrality of value-added tax. The finance is a special industry dealing with financial products, and its industries are quite complex which mainly include banking, securities, insurance, trust and leasing, etc. These industries are not the same business, for example, banking as the most important component of financial industry in China is the top priority of "the Change from Business Tax to Value-Added Tax", whose business is divided into three major parts, namely, asset business, debt business and intermediary business. Different businesses have different value-added modes and value-added degrees. In contrast, the added value of intermediary business is significantly less than asset business and debt business. The lower income tax rate of intermediate business is significantly higher than the other two types of business, which is clearly not conducive to take the neutral advantage of value-added tax. ${ }^{6}$ In addition, the loan service is the banking industry's most important asset business, and it is stipulated in the current value-added tax system that loan service refers to the business activities of obtaining interest income from giving other people capital loans. This definition involves in the traditional lending business operated by banks and loan services provided by nonbanking institutions. In this case, if a unified VAT rate is applied to the banking and non-banking institutions without distinction, obviously it is not conducive to promote the development of traditional financial services but also affect the tax neutrality of value-added tax.

\section{B. "Positive List" of Tax Scope Is Difficult to Adopt the Innovation Development of Finance Industry.}

At present, China has adopted the "positive list" legislation means in the scope of VAT for the financial industry, which stipulates the four financial businesses that belong to the financial services category of value added tax, such as loan services, direct charge of financial services, insurance services and financial products transfer. Meanwhile, it also stipulates the specific list that is available for tax-free products and business, such as interest income from financial interbank transactions, income from partial investors' transfer of financial products and tax-free interest income stipulated by the state and so on. And the corresponding definition is given.

${ }^{6}$ Dong Yi, Ma Lingjie: Difficulties and Countermeasures of China's Financial Industry in implementing "the Change from Business Tax to Value-Added Tax", published in Accounting Research, 2014, $6^{\text {th }}$ issue, Page 13.

See Annex 3 of Circular on Comprehensively Pushing out Pilot Projects on "the Change from Business Tax to Value-Added Tax" of Ministry of Finance and State Administration of Taxation: the regulations of relevant 
However, it is stipulated in this adopted "positive list" legislation the scope of value-added tax does not match the characteristics of development of financial industry. For a long time, China's various laws and regulations are lack of accurate and detailed definition of financial business. On one hand, with the rapid development of financial services and diversified forms, a large number of financial derivatives and innovative businesses such as shadow banking and offbalance sheet activities are emerging. And with the repaid development of "Internet Plus", some non-banking financial institutions, such as online payment platform, have also begun to enter the financial field in a big way, all of which constitute a great challenge to the accurate definition of financial business. On the other hand, compared with the traditional service industry, the financial business is more complex, which is often accompanied by a large number of ancillary services. Although these services are not real financial services but also closely related to financial services, such as bank management, intermediary services, rental services of safe deposit, etc. Therefore, the definition ambiguity of financial industry has been regarded as one of the important factors that affect the expansion of value-added tax to financial industry. ${ }^{8}$

In a long term, the taxation scope of "Positive list" is difficult to include future financial innovations and innovative products. There is a inevitable problem in the future that there will be the corresponding blank spots of tax in the entire financial industry, which is very bad for the regulated development of VAT system in finance industry. After all, these innovative financial products or services are not fundamentally different from other traditional financial goods or services. Therefore, taxpayers should also apply the same tax treatment paths.

\section{The Deduction Chain of VAT Has Not Been Established in Fact.}

The effective implementation of "the Change from Business Tax to Value-Added Tax" can be said to be built on whether the VAT deduction chain can be effectively established. Because in the each flow link of taxable goods or services, according to the VAT on sales, it is needed that the taxpayers shall calculate the value added tax that should be paid in this link by deducting the corresponding income tax. If the value-added tax deduction chain breaks in the middle link of circulation, the value-added tax paid by taxpayers in the link cannot be successfully carried over to the next link. So the main objective of "the Change from Business Tax to Value-Added Tax" cannot really be realized which is reducing the tax burden on taxpayers.

It is stipulated in the current value-added tax system of financial industry that goods, services, intangible assets, and real estate which the taxpayers of the financial industry purchase for business activities are allowed to be deducted unless otherwise specified by the state. But, compared with

matters: the provisions of transitional policy.

${ }^{8}$ Lei Genqiang, Xian Binzhang: Main Practice and Enlightenment of European Financial Value-Added Tax System, published in Page 75 of twelfth issue of Tax Research. other services, the fees charged by financial services providers are usually hidden in some form of spread, and each business segment will involve the verification of different deductions, While in theory, the tax collection chain shall cover all products and service, which finally realize that the value-added tax is born by the final consumer and establish relative complete deduction chain. The above special characteristics of financial service industry make it difficult to calculate the added value in the finance service. ${ }^{9}$ Therefore, the financial industry cannot be incorporated into the deduction chain of traditional invoice in practice.

In addition, in order to ensure the integrity of entire value-added tax deduction chain, the system of special invoices is applied to almost all countries that implement VAT, in which the corresponding VAT invoice will offered to the buyers when selling goods or providing services. Then the buyer can offset the output VAT by the invoice. The same is true in China. However, the current enterprise - bank - tax department between tax collection and tax system in the computer system is difficult to meet the system of VAT invoice in general sense. ${ }^{10}$ In addition, many financial business incomes are based on the profits rather than clear charge and commission, which results that such invoice deduction tax law has some difficulties in its application. ${ }^{11}$

In fact, because of the particularity and universality of customers the financial industry can not only conduct the deduction by tickets. And internationally, there is even a view that there is no method that can actually carry out the value-added tax in the financial industry as well as improve the method of tax deduction. As pointed out by Alan A Tate, a tax expert at IMF, there is no method that has a perfectly satisfactory value-added tax and allows customers to offset tax. ${ }^{12}$ China's financial value-added tax system is also facing the same predicament.

\section{FEASIBLE APPROACHES TO IMPROVE THE VALUE- ADDED TAX SYSTEM IN CHINA'S FINANCIAL INDUSTRY}

Value added tax (VAT) is the object of Taxation in the process of circulation of commodities (including taxable services and taxable services), which is considered as a relatively "neutral" tax. This is the proper meaning that Chinese government conducts the reform known as "the

\footnotetext{
Lei Genqiang, Xian Binzhang: Main Practice and Enlightenment of European Financial Value-Added Tax System, published in Page 75 of twelfth issue of Tax Research.

${ }^{10}$ Research group of Zhengzhou Central Sub Branch of People's Bank of China: International Comparison of Collection of Value-Added Tax in Financial Industry and Research on the Plan of "the Change from Business Tax to Value-Added Tax" in China's Banking Industry, published on Review of Financial Development, 2015, 2nd issue, Page 126.

"Wei Tao, Cai Hongying: Change from Business Tax to Value-Added Tax the Financial Industry: Experience and Enlightenment from France, published in Journal of Hubei University of Economics, May 2014, Page 93.

VAT: International Practices and Issues, 1992 edition, written by Alan.A.Tate [U.S.], translated by Institute of Tax Science of State Administration of Taxation, published by China Financial and Economic Publishing House and transferred from Huang Zheng: Study on Tax System of Financial Services, which is the master's thesis of China University of Political Science and Law in 2010.
} 
Change from Business Tax to Value-Added Tax". In order to maximize the neutral advantage of value-added tax, in view of the problems existing in the value-added tax system of China's financial industry at present, it is suggested to reform and improve in the following two aspects:

\section{A. Further Adjustment of Tax Scope of VAT in Finance Industry}

In principle, the financial industry shall pay taxes for the service charge or other fees as the goods or services in tax scope of VAT. The difficulty is that when determining the standard of interest or commission, the charge shall be distinguished from other elements. While other elements include the actual cost of the capital involved, the credit risk involved in the transaction and the inflation rate during the transaction. The transaction that involves these elements is also known as the main financial service. Then almost every country conducts some tax-free policies for financial service.

The current value-added tax system of the financial industry in China has basically continued the relevant provisions of business tax in the scope of tax payment (including taxable and tax-free items): After the implementation of "the Change from Business Tax to ValueAdded Tax", the previous taxable items such as loan services, direct fees, financial services, insurance services and financial commodity transfer shall be the scope of VAT; While the tax-free items will continue to enjoy the exemption from VAT, such as treasury bonds, interest income from local government bonds, interest income the People's Bank of China loaned to the financial institutions and income from financial products transferred by the individuals and so on. About the short-term effect, this approach is conducive to the smooth transition of "the Change from Business Tax to Value-Added Tax". But in a long term, for the indistinct extension, there is still some distance to the real neutral value-added tax.

The reasonable tax system should reduce the distortion to market as much as possible while realizing the revenue of the government. About the value-added tax system, it is the tax that the taxpayers pay to the tax authorities in each step of the transfer. It should be equivalent to the amount of tax calculated on the basis of value created in this process. In this way, "value, added" two words in value-added tax can well reflect the technical characteristics of tax collection. ${ }^{14}$ In this case, it is suggested that, in the next step of reform and improvement process of value-added tax, the scope of value-added tax should be adjusted on the basis of protection of tax neutrality. We can use the experience of international classification of financial services for reference, then divide the financial industry into explicit and implicit services, and determine the scope of tax and the applicable tax-free treatment based on the characteristics of two services.

V. Turuoni: Draft and Design of Tax Law, China Tax Press, 2004 edition, Page 219.

${ }^{14}$ Wei Tao, Cai Hongying: Change from Business Tax to Value-Added Tax the Financial Industry: Experience and Enlightenment from France, published in Journal of Hubei University of Economics, May 2014, Page 93.

\section{B. Further Improvement of Deduction Chain of VAT}

In theory, the collection chain of VAT shall cover all products and service, which can realize that the final consumers take the value-added tax and establish relative complete deduction chain. ${ }^{15}$ While some special characteristics of service industry make it difficult to confirm the value-added part in the finance service, even some fixed defects in invoice system, all of which eventually make the traditional VAT deduction system encounter many obstacles in the financial industry.

At present, there are three main types of value-added tax deductions in the world, namely, proportion deduction method, direct distribution method and limit method of minimum deduction. Although these three models have advantages and disadvantages, such as the fixed deduction proportion of proportion deduction method is artificially designed, which is lack of theoretical and scientific basis. And the direct distribution method will increase the VAT tax cost, and the limit method of minimum deduction will increase the possibility of tax evasion. But in view that our country's tax reducing system of finance industry has not been established actually, and there are not complete condition in the current level of tax collection and management and the management system of special valueadded tax invoice in China. In the next step of the reform of value-added tax system in financial industry, considering the experience of other countries, it is suggested that we should introduce the fixed proportion deduction method of the input VAT, so as to give full play to the advantage of value-added tax system. In fact, as early as 2006, the International Monetary Fund had made specific proposals for the reform of China's financial industry tax system, that is, "Comprehensive Law" and "Dichotomy". It is suggested in "Dichotomy" that we can refer to the paths of Australia and Singapore that the VAT return target shall be determined by the tax authorities according to the different types of financial service providers, and the return rate of income tax shall be determined on the basis of the specific types of business. 16Although the suggestion was put forward when the business tax was still available for our country's finance industry, it still has some certain significance.

\section{CONCLUSION}

As an important tax reform project and an important content of structural tax reduction, "the Change from Business Tax to Value-Added Tax" is aimed to improve the tax system, eliminate repeated taxation, adjust and optimize the economic structure, and vigorously boost the development of service industry. Finance is the important part in the modern service industry, which is of strategic importance to the development of national economy. As the largest VAT operator and the second largest economy and the largest developing country with value-added tax management experience of over 40 years, China has the ability to export the "Chinese experience" that is design and

${ }^{15}$ Lei Genqiang,Xian Binzhang: Main Practice and Enlightenment of European Financial Value-Added Tax System, published in Page 75 of twelfth issue of Tax Research. 
management of value-add tax system in finance industry to the world, and contribute to the development of world's value-added tax system. ${ }^{17}$ Considering the degree of innovation development and complexity of finance business, the reform of "the Change from Business Tax to ValueAdded Tax" of China's financial industry will be a long-term process of exploration and improvement. So what kind of value-added tax system is the most suitable one to promote the healthy development of Chinese finance industry? It is necessary to for the academic and practical circles to pay close attention to the development trend of financial industry and learn from international experience. Then considering the actual situation of China, they should build a more perfect value-added tax system in the financial industry.

\section{REFERENCES}

[1] OECD: Consumption Tax Trends 2014: VAT/GST and Excise Rates, Trends and Policy Issues. OECD Publishing. 19 Dec 2014

[2] Fan Yong: Steady Promotion of Reform of Financial Industry's "the Change from Business Tax to Value-Added Tax", published in Financial Times, version 004, April 16, 2016.

[3] See Annex 3 of Circular on Comprehensively Pushing out Pilot Projects on "the Change from Business Tax to Value-Added Tax" of Ministry of Finance and State Administration of Taxation: the regulations of relevant matters: the provisions of transitional policy.

[4] China Securities Network: Li Keqiang: Ensure that the tax bearing of "the Change from Business Tax to Value-Added Tax" in financial industry is only reduced but not increased. http://finance.sina.com.cn/roll/2016-06-21/docifxtfsae5978072.shtml,visited in August 24, 2016.

[5] He Jian: Discussion on practice path of "the Change from Business Tax to Value-Added Tax" in China's Financial Industry, published in Gansu Finance, 2015, 3rd issue, Page 60

[6] Dong Yi, Ma Lingjie: Difficulties and Countermeasures of China's Financial Industry in implementing "the Change from Business Tax to Value-Added Tax", published in Accounting Research, 2014, 6th issue, Page 13.

[7] See Annex 3 of Circular on Comprehensively Pushing out Pilot Projects on "the Change from Business Tax to Value-Added Tax" of Ministry of Finance and State Administration of Taxation: the regulations of relevant matters: the provisions of transitional policy.

[8] Lei Genqiang, Xian Binzhang: Main Practice and Enlightenment of European Financial Value-Added Tax System, published in Page 75 of twelfth issue of Tax Research.

[9] Lei Genqiang, Xian Binzhang: Main Practice and Enlightenment of European Financial Value-Added Tax System, published in Page 75 of twelfth issue of Tax Research.

[10] Research group of Zhengzhou Central Sub Branch of People's Bank of China: International Comparison of Collection of Value-Added Tax in Financial Industry and Research on the Plan of "the Change from Business Tax to Value-Added Tax" in China's Banking Industry, published on Review of Financial Development, 2015, 2nd issue, Page 126.

[11] Wei Tao, Cai Hongying: Change from Business Tax to Value-Added Tax the Financial Industry: Experience and Enlightenment from France, published in Journal of Hubei University of Economics, May 2014, Page 93.

[12] VAT: International Practices and Issues, 1992 edition, written by Alan.A.Tate [U.S.], translated by Institute of Tax Science of State

16 Huang Zheng: Study on Tax System of Financial Services, the master's thesis of China University of Political Science and Law, 2010.

17 Fan Yong: Steady Promotion of Reform of Financial Industry's "the Change from Business Tax to Value-Added Tax", published in Financial Times, version 004, April 16, 2016
Administration of Taxation, published by China Financial and Economic Publishing House and transferred from Huang Zheng: Study on Tax System of Financial Services, which is the master's thesis of China University of Political Science and Law in 2010.

[13] V. Turuoni: Draft and Design of Tax Law, China Tax Press, 2004 edition, Page 219.

[14] Wei Tao, Cai Hongying: Change from Business Tax to Value-Added Tax the Financial Industry: Experience and Enlightenment from France, published in Journal of Hubei University of Economics, May 2014, Page 93

[15] Lei Genqiang,Xian Binzhang: Main Practice and Enlightenment of European Financial Value-Added Tax System, published in Page 75 of twelfth issue of Tax Research.

[16] Huang Zheng: Study on Tax System of Financial Services, the master's thesis of China University of Political Science and Law, 2010.

[17] Fan Yong: Steady Promotion of Reform of Financial Industry's "the Change from Business Tax to Value-Added Tax", published in Financial Times, version 004, April 16, 2016. 